FESIBE

Fundación Emilio Soldevilla para la Investigacion y Desarrollo

enpresa insitutua

\section{Management Letters / Cuadernos de Gestión}

\author{
journal homepage: http://www.ehu.eus/cuadernosdegestion/revista/es/
}

ISSN: 1131-6837 / e-ISSN: 1988-2157

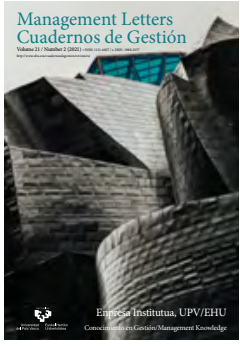

\title{
Introduction to the Special Section: Innovation
}

\section{Introducción a la Sección Especial: Innovación}

\section{António Carrizo Moreira}

Master in Management, University of Porto. PhD Management, University of Manchester. Department of Economics, Management, Industrial Engineering, and Tourism. GOVCOPP. University of Aveiro, Portugal - amoreira@ua.pt - http://orcid.org/0000-0002-6613-8796

\section{A R T I C L E I N F O}

Available online 19 May 2021

DOI: $10.5295 / \mathrm{cdg} .211470 \mathrm{ac}$

JEL CODES: M15, O32.

\begin{abstract}
A B S T R A C T
This special issue of the Management Letters / Cuadernos de Gestión is dedicated, on one hand, to presenting those articles that are included as part of the special issue on innovation and, on the other hand, to disclose the top priorities on innovation research taking into account challenging topics we are witnessing in the business world that fuel research creativity. The first part of this editorial presents the four articles that make up this special issue on innovation. The second part of this editorial addresses the main topics of the shifting landscape innovation faces: business model innovation, artificial intelligence, Industry 4.0, Internet of things, innovation ecosystems and gamification.
\end{abstract}

Keywords: Information Technology; Technology-related Startups; Technology Transfer Offices; Strategic Groups; Competitive Dynamics; Innovation.

\section{R E S U M E N}

Este número especial de Management Letters / Cuadernos de Gestión está dedicado, por un lado, a presentar los artículos que forman parte del número especial sobre innovación y, por otro, a dar a conocer las principales prioridades en materia de investigación sobre innovación teniendo en cuenta los temas desafiantes a los que asistimos en el mundo empresarial y que alimentan la creatividad investigadora. La primera parte de este editorial presenta los cuatro artículos que componen este número especial sobre innovación. La segunda parte de este editorial aborda los principales temas del cambiante panorama al que se enfrenta la innovación: la innovación en los modelos de negocio, la inteligencia artificial, la Industria 4.0, el Internet de las cosas, los ecosistemas de innovación y la gamificación.

Palabras clave: Tecnología de la Información; Empresas Emergentes relacionadas con la Tecnología; Oficinas de Transferencia de Tecnología; Grupos Estratégicos; Dinámica Competitiva; Innovación. 
Being innovative has always been challenging. Innovation is critical in today's business world as it requires novelty, i.e. bringing new ideas to firms, markets or the world. However, it needs to be tuned into a meaningful problem. As such, one can argue that innovation is normally associated with the process of adding value through the application of meaningful, novel solutions to specific problems. With this approach one can depart from the typical definitions and concepts that typically address innovation from a product, process, organizational, and marketing perspective. As such, the four articles included in this section address newness and add value in very specific ways.

The study on leadership and innovation on technology-based startups, authored by Abadía (2021), concluded that disruptive success only occurs if visionary leadership is present. Furthermore, disruptive/radical innovation is a necessary condition for disruptive success. He also concluded that "location in specialized clusters is a critical factor in determining the rate and level of success of technology-based firms." In his article 'Study on leadership and innovation: clues for success in technology-related startups', Abadía (2021) followed two different methodological strands: one rested on statistical analyses of four different databases with data from technology-based startups in the United States of America (USA) and Spain; and the other rested on nine case studies of particularly successful technology-based startups in the USA, Spain, China and Japan. Based on the former, he concluded that research and development (R\&D)-or innovation-based investment, human capital quality-based investment, and the location of technology-based startups in specialized clusters-are factors that decisively influence the rate and level of success of technology-based startups during the introduction and growth stages. Furthermore, the nine case studies showed that visionary leadership as well as disruptive/radical innovation are necessary conditions for disruptive success, and most of the successful cases are located in specific clusters.

In the second study of the special section on innovation, Santos Castellanos (2021) analyzed the impact of information technology (IT) governance on business-IT alignment. In order to do that, he adopted a covariance-based structural equation model technique with a confirmatory factor analysis to evaluate the relationship between IT governance and business-IT alignment. Based on data collected from 672 webbased responses (from three surveys with 126, 107 and 339 responses of companies in Colombia, and using 13 first-order constructs-structures, processes, relational mechanisms, aggressiveness, analysis, defensiveness, futurity, proactiveness, riskiness, IT environment scanning, strategic use of IT, IT planning and control, and IT acquisition and implementation-he concluded that IT governance significantly and directly affects business-IT alignment. Moreover, he found that there were no differences per industry type or company size, which indicates certain homogeneity among the analyzed firms. This research clearly indicates the necessity of proper IT governance of firms to align their business-IT practices.

The third paper of this special section on innovation addresses a noble objective: the development of the universityenterprise relationship based on a viable model that underpins continuous education, consultancy, collaborative R\&D, and technology transfer between stakeholders. Based on universities' third-mission, Taouaf et al. (2021) proposed an effective and efficient institutional technology transfer (TT) policy backed up by a complete repository related to the establishment of a university technology transfer office (UTTO). For that purpose, the authors proposed a business-like framework that considers the different maturity levels that characterize TT activities in Moroccan universities. They developed a plan to implement UTTO assignments, services, roles, conditions, operating standards, components, objectives, a mission statement, and an organizational chart. Nevertheless, these authors claimed that public authorities need to be aware of the importance of promoting innovation to integrate all Moroccan stakeholders into the knowledge economy to ensure that a high competitiveness level results in a successful outcome.

Finally, this special section on innovation also includes an article on competitive dynamics in which Rosário et al. (2021) analyzed the Portuguese retail banking industry in three different time periods: 2008-2010; 2011-2013; and 2014-2016. The novelty of their approach is that they took into account the financial and economic assistance program (FEAP), which is monitored by the European Commission, the European Central Bank, and the International Monetary Fund, because of the difficult economic situation that Portugal underwent in 2011. After analyzing the Portuguese banking industry-based on data collected from the Banco de Portugal database and using strategic groups and competitive dynamics theory-these authors concluded that there were three main types of strategic groups: universal banking, traditional banking and specialized banking- as a result of their dissimilar resources and competitive strategies. They also concluded that the three periods were completely different: the 2008-2010 period was considered as 'deregulated', in which the banks were not prepared for the difficult contextual events; 2011-2013 was a period of 'imposed regulation', in which the main stakeholders of the FEAP imposed tight financial controls; and 2014-2016 was a period of 'strategic consolidation', in which strategic changes were implemented as a result of the low mobility barriers in the banking industry.

\section{Innovation: a shifting landscape}

Globalization did not occur overnight. It has evolved over time, though with exponential growth in the last forty years. It brought about the acceleration of cross-border innovation. As with globalization, innovation did not occur overnight either. It has grown steadily, incrementally, and radically, giving new lives to life.

Innovation has been fed by the relentless growth of international collaborations, international trade, and the use of patents, which have had a profound impact on emerging countries' growth (and which have caused the downfall of some). Innovation does not take place homogeneously, industry wise or country wise. It needs to be promoted with an open mind.

Although innovation takes many different strands, and it is impossible to cover the main future trends, one can argue that 
there are several strands that will be important in the near future. As such, I would like to propose the following ones as having the most novel, added value for all stakeholders involved in innovation: business model innovation (BMI), artificial intelligence (AI), Industry 4.0, Internet of Things (IoT), innovation ecosystems and gamification.

Business model innovation is certainly not something new. It has historically facilitated firms' ability to create and capture value. It emerged based on Osterwalder and Pigneur's (2010) proposed concept. Although there are countless papers on the subject, there is still room for brand new service economy research, namely the health industry as well as the not-for-profit sector, for different reasons. In the former case, the health industry still needs a more business-like perspective in the provision of services. In the latter case, as most organizations struggle to survive due to a lack of resources as well as poor business orientation, BMI might help to provide evidence of why some of them thrive and some of them still struggle to survive. Furthermore, there is still a huge gap addressing bottom of the pyramid markets and companies/ organizations, which could entail brand new perspectives for BMI.

Natural intelligence is normally displayed by humans and animals and involves consciousness and emotions. However, artificial intelligence is the type of intelligence demonstrated by machines (e.g. Vlačić et al. 2021). With the relentless pace of digital and technological evolution, innovation studies addressing how AI will affect marketing, strategy, leadership, and consumer behavior are in high-demand as fast-paced AI activities will considerably affect future supply (firms) and demand (consumers) interactions. Furthermore, it will have consequences for product and services and for how consumers will be served. AI will certainly have pervasive effects on business activities throughout the world. It is a must for future studies.

Industry 4.0 is also known as the fourth industrial revolution; it involves the digital transformation of production and related industries as well as all value creation processes, and it represents a new stage in the organization and control of the industrial value chain (Fromhold-Eisebith et al. 2021).

Industry 4.0 is composed of cyber-physical systems (e.g. 'smart machines') that use modern control systems, as well as embedded software systems, to connect to Internet addresses that can be reached through IoT. Thus, all means of production and end products can communicate, enabling new production methods, value creation, and real-time optimization. For that it is necessary to create a network of products, factories and smart machines and also develop new capabilities to enable and explore new industrial systems. Their applications are endless, as, for example, in the energy systems as well as in the health industry (Ghobakhloo and Fathi 2021).

The Internet of Things is another technology-based change that will affect the way consumers and firms interrelate. IoT is related to the network of physical objects-things or objectsthat are embedded with sensors, software, and other technologies that aim to facilitate the connection and data interchange with other devices and systems that use the Internet as a means of communication (Haaker et al. 2021). The IoT will probably evolve to include multiple technologies (including AI, automation, and embedded systems), which will drive new products, services, concepts, and things that have a pervasive effect on consumer, organizational and industrial applications; this will change how firms and consumers interact. Similarly to AI, IoT will alter manufacturing and services applications, how the medical/healthcare industry works, and how smart cities and smart territories will be addressed.

Innovation does not take place in isolation. Rather, it is the effort of complex relationships between actors and entities that work together to enable the development of socio-economic and technological innovation (Scaringella and Radziwon 2018; Radziwon and Bogers 2019). As such, one can claim that the innovation ecosystem is what really matters because it involves the dynamics of relational actors that share resources, human knowledge and capital among all the entities involved. The resources include funds, equipment, facilities, etc. that support innovation development. Knowledge and human capital involve all the industry workers, managerial staff, industry researchers, students, faculty members and staff, industry representatives, among others, who support the involvement of the institutional entities that participate in the ecosystem. The entities encompass business firms, angel and venture capitalists, policy makers, higher education institutions, industry-university research institutes, federal or industrial supported centers of excellence, and state and/ or local economic development agencies, among others, that drive innovation from fundamental research to the marketplace. This innovation ecosystem is at the heart of the evolution of innovation because it involves multiple actors and entities that need to be intertwined if innovation is to thrive (Järvi et al. 2018; Benitez et al. 2020; Linde et al. 2021).

Gamification approaches use game-based elements in non-gaming contexts to encourage users to perform desired behaviors (Dale 2014, Patrício et al. 2018; Patrício et al. 2020); it is also used to develop possible solutions to overcome the encountered difficulties when managing the early stage of innovation through more structured, engaging and game-like activities. It can also be defined as a set of activities and processes that seek to use or apply game elements' characteristics to develop new products or to provide new services. Although it is not a new concept, the use of gamification has increased, providing new organizational solutions and the provision of new services.

As referred to above, innovation growth is relentless. Only the future will tell if these strands will be really important. You are invited to join this journey.

\section{References}

Abadía, A., 2021. Estudio sobre el liderazgo y la innovación: Las claves del éxito en startups tecnológicas. Management Letters / Cuadernos de Gestión, 21 (2), 109-118. doi: 10.5295/cdg.191140aa

Benitez, G., Ayala, N. and Frank, A., 2020. Industry 4.0 innovation ecosystems: An evolutionary perspective on value co-creation. International Journal of Production Economics, 228, 107735. doi:10.1016/j. ijpe.2020.107735 
Dale, S., 2014. Gamification: Making work fun, or making fun of work? Business Information Review, 31 (2), 82-90. Doi: 10.1177/0266382114538350

Fromhold-Eisebith, M., Marschall, P., Peters, R. and Thomes, P., 2021. Torn between digitized future and context dependent past - How implementing 'Industry 4.0 ' production technologies could transform the German textile industry. Technological Forecasting and Social Change, 166, 120620. doi:10.1016/j.techfore.2021.120620

Ghobakhloo, M. and Fathi, M., 2021. Industry 4.0 and opportunities for energy sustainability. Journal of Cleaner Production, 295, 126427. doi:10.1016/j.jclepro.2021.126427

Haaker, T., Ly, P., Nguyen-Thanh, N., and Nguyen, H., 2021. Business model innovation through the application of the Internet-of-Things: A comparative analysis. Journal of Business Research, 126, 126-136. doi:10.1016/j.jbusres.2020.12.034

Järvi, K., Almpanopoulou, A. and Ritala, P., 2018. Organization of knowledge ecosystems: Prefigurative and partial forms. Research Policy, 47, 1523-1537. doi:10.1016/j.respol.2018.05.007

Linde, L., Sjödin, D., Parida, V. and Wincent, J., 2021. Dynamic capabilities for ecosystem orchestration. A capability-based framework for smart city innovation initiatives. Technological Forecasting and Social Change, 166, 120614. doi:10.1016/j.techfore.2021.120614

Osterwalder, A. and Pigneur, Y., 2010. Business Model Generation: A Handbook for Visionaries, Game Changers, and Challengers. Hoboken, NJ: John Wiley \& Sons Inc.

Patrício, R., Moreira, A.C. and Zurlo, F., 2018. Gamification approaches to the early stage of innovation. Creativity and Innovation Management, 27 (4), 499-511. doi: 10.1111/caim.12284
Patrício, R., Moreira, A.C., Zurlo, F. and Melazzini, M., 2020. Co-creation of new solutions through gamification: A collaborative innovation practice. Creativity and Innovation Management, 29 (1), 146160. doi: $10.1111 /$ caim. 12356

Radziwon, A. and Bogers, M., 2019. Open innovation in SMEs: Exploring inter-organizational relationships in an ecosystem. Technological Forecasting and Social Change, 146, 573-587. doi:10.1016/j.techfore.2018.04.021

Rosário A. T., Moreira, A. C. and Macedo, P. P., 2021. Competitive dynamics of strategic groups in the Portuguese banking industry. Management Letters / Cuadernos de Gestión, 21 (2), 119-133. doi: 10.5295/cdg.180975ac

Santos Castellanos, W., 2021. Impact of information technology (IT) governance on business-IT alignment. Management Letters / Cuadernos de Gestión, 21 (2), 83-96. doi: 10.5295/cdg.180995ws

Scaringella, L. and Radziwon, A., 2018. Innovation, entrepreneurial, knowledge, and business ecosystems: Old wine in new bottles? Technological Forecasting and Social Change, 136, 59-87. doi:10.1016/j. techfore.2017.09.023

Taouaf, I., Attou, O., El Ganich, S. and Arouch, M., 2021. The technology transfer office (TTO): Toward a viable model for universities in Morocco. Management Letters / Cuadernos de Gestión, 21 (2), 97-107. doi: 10.5295/cdg.191179it

Vlačić, B., Corbo, L., Costa e Silva, S. and Dabić, M., 2021. The evolving role of artificial intelligence in marketing: A review and research agenda. Journal of Business Research, 128, 187-203. doi:10.1016/j. jbusres.2021.01.055 